\title{
Student accommodation, environmental behaviour and lessons for Property Managers
}

\begin{tabular}{|r|l|}
\hline Journal: & Property Management \\
\hline Manuscript ID & PM-09-2020-0055.R1 \\
\hline Manuscript Type: & Research Paper \\
\hline Keywords: & $\begin{array}{l}\text { human behaviour, sustainability, student accommodation, climate } \\
\text { change, environmental action }\end{array}$ \\
\hline \multicolumn{2}{|l}{} \\
\hline
\end{tabular}

\section{SCHOLARONE \\ Manuscripts}




\section{Student Accommodation, Environmental Behaviour And Lessons For Property Managers}

\section{Purpose}

Humans have been aware of climate change and greenhouse gas emissions (GHG) emissions for over three decades however, per capita GHG and water consumption increase, and environmental impacts, grow. The built environment overall contributes around $40 \%$ of total global GHG emissions and action is vital. Whilst the built environment industry, professions, regulators and stakeholders have acted; increasing building code standards and developing building rating tools and technology to reduce energy and water consumption exists, our environmental impact grows because of human behaviour. In the tertiary education sector. student accommodation constitutes a large part of the real estate of the university; and contributes large amounts of their GHG emissions and environmental impact. Property Managers have the ability to educate and install systems and technologies to improve behaviour if they understand it.

\section{Design/methodology/approach}

This exploratory pilot study used a questionnaire survey to explore how student's worldviews differ to one another and the possible subsequent limitations to behaviour in the context of climate change. Analysis is conducted based on 71 responses from international university students living in residential accommodation on campuses in Stockholm.

\section{Findings}

The results suggest that there are different perceptions about the environment and the actions that are needed, and; that this leads to different behaviours amongst students. The findings suggest that the limited knowledge and ability to relate environmental consequences to one's own actions, as well as effective communication and risk averse behaviour, is one of the critical factors in mitigating climate change. A deeper understanding of participants worldviews and the different resulting behaviours was achieved through the survey.

\section{Research limitation}

This pilot study was conducted with the participation of a relatively small number of university students. It is recommended that future studies expand the number of participants, including representatives with more varied backgrounds, education levels and different age groups.

\section{Originality}

The knowledge gained about environmental attitudes and human behaviour can help policy makers, regulators and particularly property managers to develop more effective strategies to deliver better sustainability outcomes.

Keywords: behaviour, sustainability, climate change, environment, action 


\section{Introduction}

Though we have known about climate change and greenhouse gas (GHG) emissions for over three decades, in Australia per capita GHG emissions and water consumption have increased, and our environmental impacts, such as waste, grow (Hunt and Watkiss, 2011)_Preston and Jones, 2006). During this period the built environment industry, professions, regulators and stakeholders have taken many actions. There have been increases in energy standards in building codes, enactment of planning policies, development of sustainable building rating tools for all property types, as well as voluntary actions. The Australian Green Star rating tool covers various building types in the 'as designed' and 'as built' phases of building lifecycles. The best opportunity to consider and enhance building performance lies at the initial design and building operation stages (Kibert, 2016). The technology exists to reduce energy and water consumption, and to ensure optimum air quality and IEQ metrics are delivered. Furthermore, this technology continuously improves and equipment specified today, is better than what was available even one to two years ago.

Allouhi et al (2015) analysed past International Energy Agency (IEA) data and looked at forecasts for future trends of energy consumption. The 2013 IEA report presented a figure of world final energy consumption and world $\mathrm{CO}_{2}$ emissions from 1971 to 2011 and concluded global energy consumption and $\mathrm{CO}_{2}$ emissions approximately doubled during the period (Allouhi et al., 2015). Although the latest statistics suggest that $\mathrm{CO}_{2}$ emissions curve has flattened, the change is slow and varies significantly between regions ("International Energy Agency (IEA) Global CO2 emissions," n.d.).

Allouhi et al (2015) concluded total energy consumption is growing faster than global population (2.75\% compared to $1.4 \%$ ). The growth is due to increasing needs for individual energy and per capita energy consumption had grown by $11.18 \%$ in the 10 years from 2001 to 2011, due to improvements in comfort levels and the growth of human activities. $\mathrm{CO}_{2}$ emissions had relatively higher growth rates, with a 33\% increase during this period (Allouhi et al., 2015).

The report "International Energy Outlook 2013" by the Energy Information Administration (Sieminski, 2013) predicts world energy consumption will grow 56\% from 2010 to 2040 with significant environmental impacts expected. Although the growth is predicted mainly in non-OECD countries, OECD countries such as; Australia and Sweden, will increase their consumption and will be affected by the environmental impacts. The case for changing environmental behaviours is clear, however a deeper understanding of how people are acting is needed.

It should follow with improvements in technology, rating tools and efficiency gains that lower per capita energy and water consumption would result, and therefore, given the reported increases, something is wrong. It may be over-optimism at design stage, or during construction corners are cut, or insufficient/inadequate inspections are undertaken to ensure energy efficiency results. Another aspect to consider is the commissioning of building services (Xiao and Wang, 2009). If there are the means to design, build and operate better performing, more sustainable buildings; why is it not happening to a greater extent, and; to the extent needed to mitigate climate change? Part of the issue is behaviour; human behaviour (Stevenson and Leaman, 2010).

Literature shows various interventions can be employed in the built environment in order to stimulate behavioural change (Abrahamse et al., 2005; Allcott and Rogers, 2014; Carrico and Riemer, 2011; Gynther et al., 2012; Hammink et al., 2019), whereas some interventions suggest improvements, the long-term effect on behavioural change is uncertain (Abrahamse et al., 2005; Allcott and Rogers, 2014). 
Property Managers are in a good position to influence change within the buildings they manage. Property Managers are employed in the private and public sector and are responsible for effective management of their properties. The properties they manage can be commercial, retail, industrial or residential. Residential stock is of interest because occupants spend a lot of time in the properties and their environmental behaviours contribute substantially to environmental impacts of the building.

This paper examines various types of human behaviour identified by environmental psychologists in respect of sustainability and actions and the crucial relationship in the delivery of better outcomes in building performance (Gifford, 2015); here in university residential accommodation. Buildings and their occupants are in symbiosis and the final output in respect of sustainability performance depends on both equally, this paper focuses on building residents and how human action in the built environment can be supported and consequently; pro-environmental behaviour can be enhanced. As a result there are lessons for property managers to use to reduce environmental impact though a greater understanding of residents behavioural characteristics.

\section{Human behaviour and environmental action}

Human behaviour in context of climate change has generated extensive discussion among the research community. Prominent scholars have presented reviews and proposed various research agendas on the subject (Doherty and Clayton, 2011; Gaspar, 2013; Gifford and Nilsson, 2014; Steg and Vlek, 2009; Stern, 2000). The following discussion on pro-environmental behaviour is based on the work of environmental psychologists who have researched the lack of environmental action and found 29 Dragons or, 'drag-ons' of inaction, grouped into seven categories (Gifford, 2011). Environmental related inaction has three phases; genuine ignorance is first, phase two, where various psychological processes interfere with effective action; and finally, phase three, where some action is taken (Gifford, 2011). Often this action quickly fades to inaction, as action taken makes too little transformation to the individuals environmental footprint or, is counter-productive as witnessed in the 2018 disclosures about ineffective, bogus and non-compliant recycling and landfill practices (MacKenzie, 2018).

Overall, there is a lack of data, awareness and understanding, or limited cognition, about issues relating to advice that could be given at the design stage in respect of lifecycle building performance and, during construction to reduce environmental impact and improve operation (Osmani et al., 2008). This information/knowledge gap covers waste, water usage, lowering of GHG emissions, use of green building rating tools or; options of exceeding the minimum standards contained in the Building Code of Australia (BCA); all of which could future proof the development against environmental obsolescence (Ding, 2008). Limited cognition comprises seven categories of behaviour listed below:

\section{$\underline{1 . \text { Limited cognition }} \quad \underline{1.1 \text { Ancient brain }}$ \\ 1.2 Ignorance \\ 1.3 Environmental numbness \\ 1.4 Uncertainty \\ 1.5 Judgemental discounting \\ 1.6 Optimism bias \\ 1.7 Perceived behavioural control}

Some psychologists discuss a concept labelled; 'ㅅancient brain' (Ehrlich and Ornstein, 1989), assertsing human brains have not advanced greatly over millennia and that 21 st century climate change 
is too recent a phenomenon for humans to react to. Ignorance, not knowing there is a problem or, not knowing what to do, limits their action and behaviours (Bord et al., 2000). Other researchers (Gifford, 1976; Gifford and Chen, 2017; Pelletier et al., 2008) identify environmental numbness, where people are inundated with too much information and becoming selective about what data can be assimilated. If issues, such as investigating the best performance options over a building lifecycle does not lead to direct difficulties because clients do not seek this guidance, it follows that behaviours are not $\underline{\text { unlikely }}$ to alter. Conversely; it is posited-when humans see repeated information attention- and action shrink rapidly too (Burke and Edell, 1986; Newig, 2004). Here, more is actually less.

Apparent and real uncertainty, diminishes pro-environmental behaviour, vindicating inaction and well intentioned efforts of scientists, industry bodies, to quantify the level of certainty can be counterproductive (Hine and Gifford, 1996). Another behaviour;, labelled 'judgemental discounting', is where future risks are discounted. In a survey, respondents in 15 of 18 countries believed environmental problems were worse elsewhere, with the result of less motivation to act locally (Gifford et al., 2009). A sixth type of drag on action is 'optimism bias', which is where personal risks are discounted to the impairment of a person's/peoples own well-being; "she'll be right"; is-a well-known Australianism, and is an example of optimisation bias (Weinstein et al., 1988). The final limitation on action is 'perceived behavioural control and self-efficacy'; which occurs when a person believes they cannot do anything as 'an individual', and so; they do nothing (Olson, 1989).

The second group of drag on behaviours is tabelled-ideologies' and has four components listed below;

\section{Ideologies}

\subsection{Worldviews \\ 2.2 Suprahuman \\ 2.3 Technosalvation}

2.4 System justification (Martin et al., 2011) (Gifford et al, 2011).

and claims that $\mathrm{P}$-peoples worldviews are an important predicter of their action and behaviour, an example, is the faith in free enterprise or capitalism. The Freedom Of The Commons worldview has led to devastation of fisheries, forests and other landscapes (Heath and Gifford, 2006). Four sub-categories in this group are identified being; worldviews, suprahuman powers, techno-salvation and system

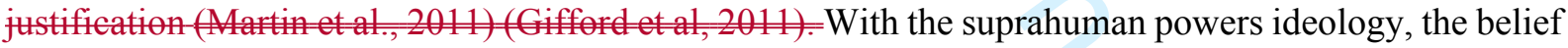
is that Mother Nature will do what it wants; anyway; humans are powerless (Mortreux and Barnett, 2009) and; consequently, action is futile. Techno-salvation is a technocentric perspective of the world which is a barrier for some, as they believe people can be saved through technological solutions (Gifford, 2008). An example of this view is the-faith that geo-engineered artificial trees will save us. System justification_is the final behaviour and is the defence of the status quo. Whereas climate change mitigation requires humans to modify behaviour, such as focusing more on lifecycle performance of buildings, investing in sustainable design and procurement, and; changing behaviour and the way humans occupy, operate and manage property (Feygina et al., 2010).

Comparison with others, is - the third group of behaviour restricting actions comprises three categories, and is where people compare what they detheir actions with to others.

\section{Comparison $\quad$ 3.1 Social comparison}

$\underline{3.2 \text { Social norms and networks }}$

$\underline{3.3 \text { Perceived inequity }}$ 
This $s$ Social comparison tendeney is referred to as the Theory of Planned Behaviour (Ajzen, 1991) or the Value Belief Norm Model (Stern, 2000). The rationale is, if your peers do not take action; neither do you. In other ways, with social norms and networks, though there is potential for progress, they alse permit regression (Thøgersen, 2008). An example occurred in a residential power use study, where residents modified actions and energy use to fit the 'norm', resulting in overall consumption increases (Schultz et al., 2007). A further drag on behaviour is perceived inequity or; 'why should I change, if others don't?' studies concluded co-operation declined where inequity was perceived. The question is; if people can acknowledge these tendencies, is it possible to be proactive to encourage positive behaviour?

Sunk costs represent 1 is the fourth another-category of behaviours impacting actions with three components;

$\underline{\text { 4. Sunk costs }}$

4.1 Financial investment

\subsection{Behavioural momentum}

\section{$\underline{4.3 \text { Conflicting values }}$}

-With financial investments, once a person has invested in something, dispensing with it is more difficult (Arkes and Hutzel, 2000); it is known as a sunk cost and is the fourth group of drag on behaviours. An example is car ownership; people are loss averse and do not want their investment to be wasted; that is 'you've bought it, so use it'. This may affect some contractors who invest in equipment to deliver developments using certain materials and methods, and this is their preferred specification when tendering. Closely aligned, is theB-behavioural momentum habit is closely aligned (Gifford, 2015). Looking at the way water and energy is-used in homes as an example, occupiers may choose the familiar behaviours over ones which may offer greater sustainability and better performance. Within households there are conflicting values, goals and aspirations that are often incompatible (Stern, 2000). Cost and quality of building materials and building services and appliances all have impacts on performance outcomes, for example, some materials have higher amounts of embodied energy compared to alternative materials. It was found thatL tack of place attachment is associated with lower pro-environmental behaviour (Clayton, 2003), and thus-people in rented homes and/or from outside a local area, may not be interested, or able, to invest in behaviour or equipment that might deliver better performance over the property lifecycle.

The fifth group of drags on behaviour identified iis discredence, which has four components;

\section{Discredence $\quad 5.1$ Mistrust \\ 5.2 Program inadequacy \\ 5.3 Denial \\ $\underline{5.4 \text { Reactance }}$}

-Trust is easily broken and when damaged, the chances of adopting pro-environmental behaviour declines (Terwel et al., 2009), this applies to building occupants. Many environmental building programmes have been developed to encourage improved performance, though few are mandatory or sanction non-compliance. Sometimes, it transpires - the programme fails to achieve objectives and consequently trust diminishes, green building programmes such as the 1200 Buildings Program in Melbourne in the mid 2000s is an example of this (Wilkinson, 2018). Another example, is the realisation in 2018/and-2019 that recycling programmes weare not working and recycled waste is ending up in landfill rather than being recycled (National Waste Report 2018. Prepared for Dept of the Environment and Energy, 2018). A consequence of this-can be cognitive dissonance, which occurs-when people 
decide a programme is not good enough for them and this-justifies their non-participation. It follows that denial in the form of uncertainty, mistrust and sunk costs can lead to denial of the problem (Norgaard, 2006). An example is climate change deniers (Dunlap and McCright, 2010), who are more outspoken than those who believe otherwise. With reactance, there is evidence that many do not trust messages from scientists and governments (Earle, 2004) and evidence that fossil fuel industries encourage this view (Hoggan and Littlemore, 2009). Facebook and Cambridge Data Analytica allegations of interference with elections (Guardian, 2018) add credibility to this assertion. The end result is that some people mistrust messages about acting in environmentally positive ways.

Perceived risk (Schiffman et al., 2006), the sixth group of drag on behaviours, has six variables that reduce actions:

\section{Perceived Risk}

6.1 Functional risk

$\underline{6.2 \text { Physical risk }}$

6.3 Financial risk

6.4 Social risk

6.5 Psychological risk

6.6 Temporal risk

-Consider an innovative technology such as ground source heat pumps or algae building technology, property managers would want to know; the functional risk (will it work?), the physical risk (is it safe?), the financial risk (what is the payback period and is the energy provided cheaper than alternatives?), the social risk (what will my colleagues/contemporaries think?), the psychological risk (will people tease me?), and; the temporal risk; time involved researching the technology (will it be wasted?). These perceived risks encourage people to stick with familiar specifications and appliances in housing, and to adhere to familiar behaviours (Martin et al., 2011). With housing providers adhering to tested specifications and technologies ensures that risk taking for improved building performance using behaviour change is a low priority. The incentive is absent, as any interest in building performance ends when the property is completed and sold to others. However, this is not the case for property managers of residential property such as student accommodation.

The final, seventh group is labelled limited behaviour which has two components;

\section{Limited behaviour $\quad$ 7.1 Rebound \\ 7.2 Tokenism}

-Once individuals get past all the preceding six 'drag-ons'; environmental numbness, denial, judgmental discounting, habit and perceived risk and think they can act; which actions are most likely? Some actions are easier than others and these are chosen more often than harder, but more effective, ones. For example, separation rubbish for recycling might be straightforward but altering behaviour to lower energy and water consumption, and monitoring it, is harder (Grifford, 2011). Eliminating plastics is a tougher option to achieve compared to recycling plastics.

The rebound effect or Jevons Paradox (Jevons, 1865) is another important consideration, where the savings made are subsequently lost in other actions (Grifford, 2011) BedZed housing ${ }_{2}$ is-a sustainable UK development where substantial energy and water savings were realised by occupants. The occupants were found to-spente the money they saved on utilities on other things including higher than average amounts of international travel (Lombardi and Trossero, 2013; Rode and Burdett, 2011). The total GHG emissions related to their additional air travel exceeded the GHG emission savings realised in the 
BedZed homes, and indicates the need to be aware of retaining the savings made in sustainable building performance (Herring, 2011).

\section{Materials and Methods}

This research examined the psychological barriers for taking action towards climate change. Following Gifford's categorisation of the psychological-barriers to climate change mitigation and adaptation (Grifford, 2011), a questionnaire survey to test the specific -manifestations of the psychological barriers was developed. This is qualitative research which seeks to gain a deeper understanding of the barriers to environmental action (Patton, 2002). The literature review generated the survey questions.

\subsection{The questionnaire}

The survey tested six of the seven barriers or drag ons: limited cognition, ideologies, comparisons with others, sunk cost, discredence and limited behaviour. The target group in this study were students living in university accommodation and given the respondents' specific-lifestyle situation, the researchers excluded the category perceived risk from the questionnaire.

The questionnaire included 23 statements reflecting 23 specific barrier manifestations. In addition, questions were added to measure respondents' perceptions of their own environmental behaviours. A total of 34 closed questions were included in the survey. The questionnaire-survey finished with an open question enabling respondents to leave comments freely. This paper focuses on general barriers only and their specific manifestations, the questions and adopted scale are presented in table 2.

\subsection{Data collection}

Data for this pilot study was collected in February 2019. The questionnaire was emailed to 309 international students studying in Sweden, living on the university campus in university students' apartments at KTH, Stockholm.

Since building and occupants are in a symbiosis, the final performance depends on both the building's sustainable conditions and the residents' behaviour. To gain a better understanding of residents' actions and their environmental profile, we conducted a study among residents in a building with a very high sustainability performance. The underlying assumption is that living in a house that has very good environmental performance has the best conditions for acting in an environmentally friendly manner. Therefore, we can assume that it is the individual's drive and psychological barriers that largely determine the behaviour of the residents.

A survey was conducted among students who lived in a student housing that is built as a plusenergy house. The student house has a very energy-efficient heating system and very good building insulation. The house is newly built and the first occupants have moved in in 2018. The recycling station is located in the close proximity to the building. Students have access to a laundry room with energy efficient dryers and washing machines.

Each student received an email inviting them to take part in a survey, with a reminder sent out 10 days after the first invitation. The online questionnaire was open for one month. As a token of appreciation, students were offered a voucher for food/coffee of approximate value of 3 Euro. 71 completed responses were received $(23 \%)$. 


\subsection{The analysis}

The questionnaire provides responses on 23 barriers. Descriptive statistics are used to present the results. Difference in responses depending on country of origin (defined as continent of origin and categorised as: Asia, Europe and America) and gender. Due to the ordered nature of the data, the KuskalWallis, a post-hoc Dunn's test, the Benjamini-Hochberg comparison method was applied where relevant. A post-hoc Dunn's test, Benjamini-Hochberg comparison method, was used computed to test statistical significance for pair comparison between groups. The post-hoc test allows for comparison of responses between groups with adjustment for multiple testing (Thissen et al., 2002). BenjaminiHochberg procedure tests difference in responses between the groups and control for the false discovery rate in multiple comparison (Thissen et al., 2002). In order to perform the statistical tests, scores were allocated for each answer: strongly agree (5), agree (4), neither agree or disagree (3), disagree (2) and strongly disagree (1); and for questions regarding social comparison the answers were ranked as follows: yes (5), no (1), and do not know (3). The analysis was conducted using statistical package STATA 14.

\section{Results}

\subsection{Respondents}

Of the 71 completed responses, $59 \%$ identified as male and $41 \%$ as women. The majority (94\%) of respondents were postgraduate students, with undergraduate students comprising $6 \%$ of respondents. Most respondents were aged between 21-24 years (65\%), a quarter were aged between 25-28 years and $10 \%$ were more than 28 years old. All respondents were international students from 33 different countries, with most coming from Germany (17\%), France (13\%), China (7\%), Spain (7\%) and India (7\%). To test differences in responses, a variable "continent" was created, which included three groups: Europe (44 respondents or 64\%), Asia (19 respondents or 28\%) and America (North and South) with $9 \%$ of respondents. Respondents studied different subjects from mathematics, computer science and industrial economics to architecture and built environment. Therefore, the respondents are highly educated, mostly aged 21-24 years and all international students, mostly European, studying a broad range of subjects in Sweden. It is acknowledged that different groups of respondents may hold different views (Macias, 2015; Vaughan and Nordenstam, 1991).

\subsection{General barriers to behaviour and action}

\subsubsection{Limited Cognition}

Gifford's (Gifford, 2011) categorisation of the psychological barrier limited cognition includes seven manifestations (biases): ancient brain bias (Ehrlich and Ornstein, 1989), environmental numbness (Gifford, 1976; Gifford and Chen, 2017), ignorance (Bord et al., 2000), uncertainty (Hine and Gifford, 1996), spatial discounting of environment (Uzzell, 2000) optimism (Weinstein et al., 1988), perceived behaviour control and self-efficacy (Olson, 1989). Those manifestations correspond to seven variables in the data set.

The survey results suggest that students are particularly-prone to perceived behaviour control and self-efficacy bias and ignorance bias. Most respondents (55\%, Table 1) agreed with statement: Individuals can affect climate change. Action does_no-t have to be at government and national levels, indicating potential bias towards perceived behaviour control and self-efficacy suggesting a weakened belief in collective actions that can solve the climate change problem (Olson, 1989). 
Table 2. Kruskal-Wallis test, $\mathrm{p}<0.05$. (Source: Authors).

\section{[PLACE HOLDER, Table 1 Environmental Behaviour Survey Questions and Responses - table attached separately due to the layout]}

Table 1. summarises the survey questions referring to the 23 different manifestations of general psychological barriers and shows the distribution of answers. All questions except one (marked) gave respondents' the possibility of five answers: strongly agree, agree, neither agree or disagree, disagree, and strongly disagree. The marked question offered three possible answers being: yes, no, or; I do not know/I do not compare.

A test for a statistical difference in opinion depending on the country of origin and gender was conducted. Based on the results from the Kruskal-Wallis (Table 2) and pair comparison BenjaminiHochberg test, the hypothesis of equality of means between the different continent groups for limited cognition variables: ignorance and judgmental discounting is rejected. The results suggested students from Europe are more confident in their knowledge and judgement, than students from Asian countries, about taking actions to mitigate climate change. The Kruskal-Wallis test suggested differences in responses for the variable environmental numbness, however, the pairwise comparison test indicated a weak significance level between groups, indicating that differences in answers between those groups does not differ at a significance level.

\begin{tabular}{llll}
\hline GENERAL & & & \\
BARRIERS & specific manifestations & gender & Continent \\
\hline 1.Limited & & & \\
cognition & 1.1 Ancient brain & 0.61 & 0.53 \\
& 1.2 Ignorance & 0.44 & 0.01 \\
& 1.3 Environmental numbness & 0.03 & 0.04 \\
& 1.4 Uncertainty & 0.70 & 0.13 \\
& 1.5 Judgemental discounting & 0.57 & 0.00 \\
& 1.6 Optimism bias & 0.28 & 0.87 \\
& 1.7 Perceived behavioural & & \\
& control & 0.81 & 0.95 \\
\hline 2 Ideologies & 2.1 Worldviews & 0.47 & 0.83 \\
& 2.2 Suprahuman & 0.44 & 0.04 \\
& 2.3 Technosalvation & 0.75 & 0.85 \\
& 2.4 System justification & 0.84 & 0.03 \\
\hline
\end{tabular}




\begin{tabular}{llll}
\hline 3. Comparison & 3.1 Social comparison & 0.29 & 0.72 \\
& 3.2 Social norms and networks & 0.51 & 0.09 \\
& 3.3 Perceived inequity & 0.80 & 0.20 \\
\hline \multirow{3}{*}{ 4. Sunk costs } & 4.1 Financial investment & 0.94 & 0.09 \\
& 4.2 Behavioural momentum & 0.82 & 0.01 \\
& 4.3 Conflicting values & 0.32 & 0.00 \\
\hline 5. Discredence & 5.1 Mistrust & 0.84 & 0.47 \\
& 5.2 Program inadequacy & 0.79 & 0.42 \\
& 5.3 Denial & 0.99 & 0.58 \\
& 5.4 Reactance & 0.92 & 0.00 \\
\hline 6. Limited & 6.1 Rebound & 0.89 & 0.15 \\
behaviour & 6.2 Tokenism & 0.93 & 0.01 \\
\hline
\end{tabular}

\subsubsection{Ideologies}

The clear barriers towards action appear when respondents beliefs affirm that the current situation cannot be changed, or give sufficient justification for accepting the situation. There are fFour variables representing four manifestations included in the barrier titled 'ideologies' barrier in Table 1. Every third student indicated that; regardless of what actions humans take, mother nature will do her thing (table 1), confirming that Mother Nature will prevail, regardless of human actions (Mortreux and Barnett, 2009).

At the same time, $30 \%$ of respondents believed in technosalvation, (Table 1) concurring that humans will find a technological solution to climate change (Gifford, 2008). 25\% agreed with the statement; I believe in capitalism, which is an economic paradigm that has led to climate change and environmental damage. This indicates more students will seek other paradigms.

A small minority accepted the current situation, while $96 \%$ disagreed with statement that; things are OK as they stand, that's why I don't need to take any action on climate change (Heath and Gifford, 2006).

The Kruskal-Wallis and pair comparison Benjamini-Hochberg test results show (Table 2) the hypothesis of equality of means for the variables 'suprahuman' and the group, continent, can be rejected, which indicates that students from Asia have a stronger belief in the power of nature than the European students. The Kruskal-Wallis test suggested differences in responses for the variable; 'system justification', however, a pairwise comparison test indicated a weak significance level between the groups, therefore, it is not possible to reject the hypothesis that students' answers are equal regardless country of origin.

\subsubsection{Comparison with others.}

Comparison with others is a strong incentive for action, butequally, may bealso a barrier (Ajzen, 1991; Stern, 2000). The actions may be triggered positively by social comparison and norms (Schultz et al., 2007). The results suggest that students-do compare themselves with others, as $72 \%$ of totat respenses-agreed with statement; If I was told that my energy usage was higher than my friends that 
would prompt me to reduce it to a comparable level (Table 1). Perceived inequity may be one of the main reasons for inaction (Schultz et al., 2007). The answers indicate this is not the case here, as only $7 \%$ of respondents acknowledged that if others are not taking actions, there is no reason for their own engagement.

\subsubsection{Sunk costs.}

There is evidence that $\underline{S}$-sunk costs may have effect on post hoc rationalisation of success of an endeavour in the climate change context (Arkes and Hutzel, 2000), it suggests that financial investment in for example, a car, would prevail in favour of using other forms of transport that are less environmentally damaging. The survey results do not support this hypothesis, as $80 \%$ of students; did not find it irrational to use a public transport even though owning a car.

Weight of habit can be a problem in taking action against climate change (Gifford, 2015). Nearly $75 \%$ students disagreed with statement; If taking action on climate change depends on me changing my daily routine quite a bit, it's not going to happen. This indicates confidence that they are in control of their behaviour, and that they did not perceive their ability to make their own behavioural change as a problem. Approximately $65 \%$ disagreed with the statement; I believe climate change is real, but I am unwilling to pay higher taxes to tackle it (conflicted values) (Stern, 2000) suggesting they are happy to pay more to take action. The results indicate that the students do not perceive their behaviour is a barrier in taking action against climate change.

\subsubsection{Discredence.}

A positive, or negative, attitude towards others views may affect the development of discredence (Gifford, 2011). Success in achieving climate change mitigation depends on public trust and acceptance (Terwel et al., 2009). One-A third of respondents agreed with a statement that they; don't trust government departments and their reports on environmental matters (Table 1).

Mistrust towards government officials may convert to reactance (Earle, 2004). Only 7\% percent of respondents felt the government was imposing too many rules and regulations about climate change (70\% disagreed, Table 1) and this-indicatinged that they accept more environmental government regulations.

Implementing various programmes is a way for government to promote and engage public, however, some may find inadequacy of a programme as a justification of own inaction (Gifford, 2011). Approximately $40 \%$ survey respondents agreed with the statement that; Policy makers programmes, for example incentives for solar panels, are good idea but there is too much paperwork.

Approximately $40 \%$ of respondents stated a neutral response, neither agreeing nor disagreeing with the statement; thus a high level of discredence was evident (Table 1). A clear majority (90\%, Table 1) disagreed with statement that; human activity has little, or nothing, to do with climate change, $10 \%$ neither agreed or, disagreed. These results suggest these students are very aware of the human contribution towards climate change.

\subsubsection{Limited behaviour.}

Nearly $60 \%$ believed that; to stop climate change, all I need to do is cut my energy consumption by $10 \%$. The responses suggested that the majority of the respondents-are very optimistic about the effect 
of their behaviour and the amount of action needed, which in turn suggested that there is a risk that the pro-environmental actions undertaken might be tokenistic at best and; totally ineffective at worst. The variable 'tokenism' was found to be statistically different depending on country of origin (KruskalWallis test, $\mathrm{p}=0.01$, respectively Table 2 ). Some mitigation effort might be offset by (rewarding) actions that normally would not take place. Respondents showed relatively modest answers, with only $10 \%$ agreeing that; after all the savings (energy, water, $\left.\mathrm{CO}_{2}\right)$ I have made, I believe I deserve a reward $(67 \%$ disagreed).

\section{Discussion}

\subsection{Understanding and overcoming barriers}

Specific manifestations which have the highest mean could potentially indicate the biases that respondents are leaning towards most. Our sample suggest that highest mean values $(>3)$ were recorded for manifestations related to limited cognition: ignorance, judgemental discounting, perceived behavioural, comparison - social norms and networks and discredence-program inadequacy (fig.1).

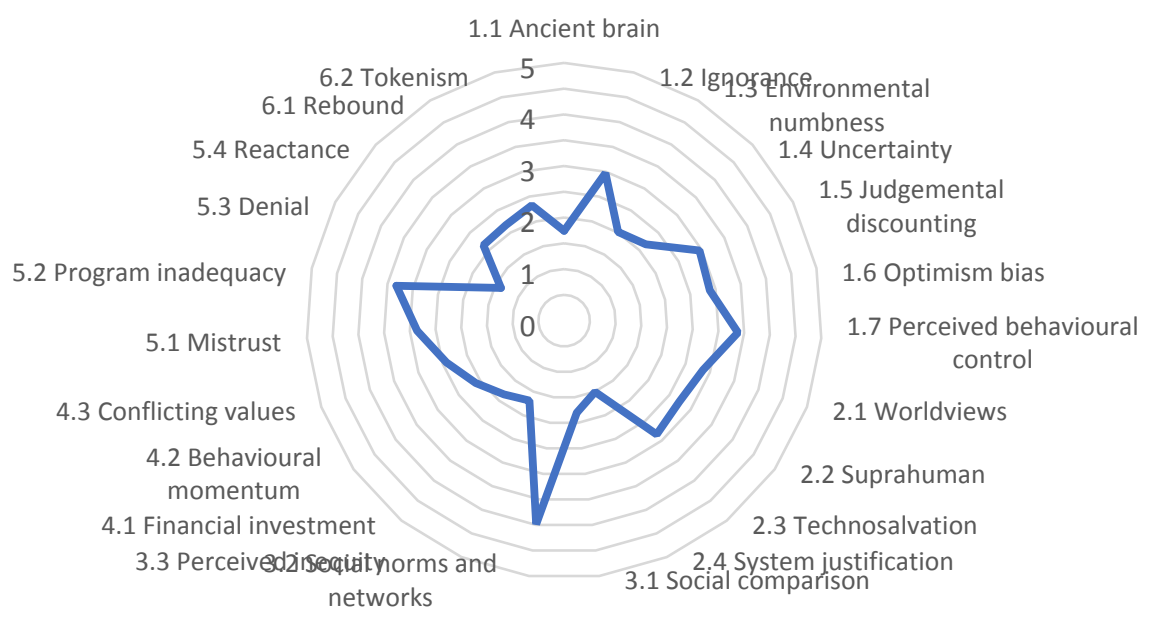

Fig. 1. Mean values for specific manifestations

Respondents indicated that they have limited knowledge about how to act toward mitigating climate change, or understanding about the consequences of various behaviours. Ignorance bias stops people from making active choices and conscious decisions about their behaviours (Bord et al., 2000), in the context of climate change. 
There are voices in scientific community suggesting that ignorance might be related to the fact that scientists and non-scientists develop understanding about climate change in different ways (Weber and Stern, 2011). Scientists have developed their understanding about climate change over generations, using various methods, for example, systematic measurements and observation, mathematical modelling and peer-reviewed research and scientific debate for years. Non-scientists are more prone to relay on personal experience (Weber, 2006), need to rely on secondary data and media coverage (Weber and Stern, 2011). Weber (Weber, 2006) argues that peoples' perception of global warming, based on personal experience, will be low due to the fact that people receive insufficient feedback from their daily life or low frequency personal experience on global warming consequences. Climate processes and their impact can be difficult to comprehend and to visualise (Nicholson-Cole, 2005).

People are using experience as input to recognise risks and creating a response mechanism. However, feedback on global warming consequences is relatively weak, therefore even though the individual is presented with relevant information, which indicates existence of a problem; the individual is failing to respond in time to affect change. People ignore of the environmental problem, which means the individual behaviour stays the same, and mitigating behaviour is never really considered. It is possible that the clues about environment ignored and condemned as irrelevant to individual situation. The research has showed that the people under estimate the effects of climate change in respect of spatial and time distances (Hatfield and Soames Job, 2001; Pahl et al., 2014, 2005). Moreover, lack of knowledge can lead to the situation that individual is not able to produce an alternative behaviour model, due to limited knowledge on what one could do to mitigate climate change or, what the consequences of behaviour in terms of environmental impact are.

Moreover, the uncertainty about effect of pro-environmental behaviour (in the context of general climate mitigation) can increase self-orientated behaviour. Evidence of self-interest behaviours are often found in situations where individuals anticipate other people will pursue self-interest behaviours (Miller, 1999). In situations when personal responsibility is associated internally (with ones' own actions) it has facilitating attributes, however, if a person attaches that responsibility to other people, organisations or government bodies, attribution function as a barrier (Gaspar et al., 2017). Research has shown that "perceived sufficiency" may function as a justification of not acting in an energy efficient way, and a preference towards ones' own comfort and wellbeing can easily overshadow positive environmental attitude (Gaspar et al., 2017). Comprehending individual responsibility and environmental self-identity may motivate towards action (Rickard et al., 2014; van der Werff et al., 2013).

The need for broader collective action, identified as one of the main factors contributing to a lack of motivation and environmental inaction (Pongiglione, 2014). Social norms can have a significant effect on people's behaviours, as generally people prefer to avoid the disapproval of peers (Miller, 1999).

\subsection{Implications for Property Managers (PM)}

Bröchner et al. (Bröchner et al., 2019) point out two main opportunities in property management: digitalisation and sustainability. The authors argue that the future of management in the properties will utilise intelligent data solutions and technological advancements to provide more efficient property management, however, in doing this must acquire better understanding of users and society. Better understanding of users unlock new possibilities of resource efficiency. 
This section highlights the key implications from the survey results for property managers.

\section{Relevant knowledge}

Increase knowledge on what one could do to mitigate climate change or and what the consequences of behaviour in terms of environmental impact are. Results from earlier Swedish research showed relationships between knowledge of causes of climate change and risk judgement (Sundblad et al., 2007) implying that it is not general knowledge about the state of the climate, but an understanding and possibility of visualising the consequences of climate change, that effect cognition and risk judgement.

\section{Increasing knowledge \& individual responsibility}

PM should learn and inform occupants about climate footprint related to operation and usage of the property; for example where the electricity is sourced, such as the percentage that is coming from wind or solar farms, and what actions increase energy consumption and the consequences for the environment; PMs can also inform occupants about how to reduce consumption levels of water and energy and reward behaviours that reduce usage. Communicating the ecological consequences may lead towards change of consumption habits (Csutora, 2012) and nudge occupants' individual responsibility towards proenvironmental actions.

\section{Green outsourcing / procurement}

In terms of energy and water and other building function related resources PM can lead by example by purchasing green energy and installing equipment to lower usage rates. They can communicate this to residents to illustrate how they are all part of solution. As large residential buildings tend to use large amounts of resources, PM can influence power in the procurement of materials with lower environmental impacts.

\section{Green leases}

Cooperation between landlord and tenant is main factor in a successful work towards pro-environmental behaviour and lifestyle. For example, the Swedish Green Lease Contract includes 16 obligatory actions and 27 voluntary actions (Fastighetsägarna, 2017), where tenants and landlords bear joint responsibility for environmental work. Even though the successful outcomes might be often due to cooperative effort, the legal binding agreement might be the incentive that helps meeting environmental targets (Rameezdeen et al., 2019).

\section{Engaging tenants in social exchange}

PMs can develop materials and host events to share knowledge and gain consensus to improve environmental actions as a group or, a collective. 


\section{Conclusions}

This research examined various types of human behaviour identified by psychologists in respect of sustainability and actions. The rationale for the pilot study is that in the 32 years since the 1987 UN Brundtland Report (Imperatives, 1987) and the promotion of the concept of sustainable development, working within the limits of the planet, with the broad acceptance within the global academic community that climate change is happening; environmental action should be commonplace. However, evidence in the built environment sector (Kibert, 2016; Xiao and Wang, 2009) is that, at best, insufficient action is being taken and; at worst, actions that damage the environment and accelerate climate change prevail.

Residential accommodation offers great potential to understand occupants behaviours and attitudes and; for property managers, to use this knowledge to develop and implement strategies to reduce environmental impacts of their buildings. In the present pilot study 71 international students responded to a survey about their environmental behaviours to benchmark against Gifford's (Grifford, 2011); groupings of different behaviour categories that drag on action being taken. The seven categories are; limited cognition, ideologies, comparison, sunk costs, discredence and limited behaviour. This study analysed 23 of the 29 dragons behaviour within six of the categories of action identified in the literature.

The responses provide evidence of biases of ignorance and perceived programme inadequacy; suggesting high self-belief and the tendency to justify one's own inactions by blaming others. Students perceive limitations of their own actions and do not perceive their behaviour as a barrier in taking action against climate change. Attributing responsibility externally is a barrier to taking action (Swim et al., 2009). Strategic communication about climate change and accentuating individual responsibility to act might give motivation and induce reflection about connection between climate change and individual choices and behaviour (Rickard et al., 2014).

The results and insights into attitudes and behaviours indicate contemporary technology opens new ways of tackling potential lack of knowledge, for example, for PMs to use just in time notifications and reminders. New technological solutions, together with better understanding on how environmental knowledge can be framed and timed, can help to reduce barriers arising from information processing, misjudgement of risk and loss aversion.

The results indicated that there is a difference in perceptions, depending on respondents' country of origin, which means that different populations may respond to messages and policies in different ways; and, to different degrees (Ceglia et al., 2015). Those findings are in line with previous studies which have found effect of culture on environmental performance (Roy and Goll, 2014). Future studies, conducted on a larger samples, will give more insights into the effects of other socio-demographic factors.

The questionnaire survey tested self-perceived behaviour, meaning that there is a possibility for a gap between self-perceived behaviour and actual actions (Kollmuss and Agyeman, 2002; Newton and Meyer, 2013) and this is a limitation of the research methodology to some extent. More studies are needed to examine the difference in the perception of one's own behaviour and the evidence of actual choices, actions and habits. Applications of digital solution enables collection of data in built environment that opens new possibilities for understanding human behaviour and cross-data analyses 
e.g. energy consumption, indoor environment, spatial movement, real time recorded actual behaviour and even individuals health data.

The results revealed variation in attitudes and evidence of biases that can impact effective action and have deepened our understanding of the underlying reasons affecting effective action. The findings suggest that limited knowledge and ability to relate environmental consequences to one's own actions, as well as effective communication and risk averse behaviours, are critical factors in mitigating climate change. Those findings are in line with previous studies (Chaplin and Wyton, 2014; Hay et al., 2019; Horhota et al., 2014). It follows that property managers, and also policy makers, regulators, home owners and occupiers all need to increase their self-knowledge of the important relationship between peoples' worldviews and how that impacts on their behaviours and taking effective environmental actions.

This research highlighted some of the complex, interactive barriers society faces in taking effective action to address climate change. This well-educated group of young people displayed very varied responses to the many of the dragons of behaviour. These findings suggest the urgent need to look more closely at finding ways to encourage positive behavioural change in all populations before it is too late. Positive behavioural action in the built environment could lead to, much needed mitigation of the significant impact of this sector.

The study contributes to a better understanding of the complex relationships between environmental attitudes and environmental behaviour. Further studies into the relationships between worldviews and human behaviours and reducing environmental impacts of buildings during their lifecycle are much needed.

This research has been founded by Swedish Research Council For Sustainable Development (201600684). 


\section{References:}

Abrahamse, W., Steg, L., Vlek, C., Rothengatter, T., 2005. A review of intervention studies aimed at household energy conservation. Journal of Environmental Psychology 25, 273-291. https://doi.org/10.1016/j.jenvp.2005.08.002

Ajzen, I., 1991. The theory of planned behavior. Organizational behavior and human decision processes 50, 179-211.

Allcott, H., Rogers, T., 2014. The Short-Run and Long-Run Effects of Behavioral Interventions: Experimental Evidence from Energy Conservation. American Economic Review 104, 3003-3037. https://doi.org/10.1257/aer.104.10.3003

Allouhi, A., El Fouih, Y., Kousksou, T., Jamil, A., Zeraouli, Y., Mourad, Y., 2015. Energy consumption and efficiency in buildings: current status and future trends. Journal of Cleaner Production 109, 118-130. https://doi.org/10.1016/j.jclepro.2015.05.139

Arkes, H.R., Hutzel, L., 2000. The role of probability of success estimates in the sunk cost effect. J. Behav. Decis. Making, 0894-3257 13, 295-306. https://doi.org/doi:10.1002/1099-0771(200007/09)13:3<295::AIDBDM353>3.0.CO;2-6

Bord, R.J., O'connor, R., Fisher, A., 2000. In what sense does the public need to understand global climate change? Public understanding of science 9, 205-218.

Bröchner, J., Haugen, T., Lindkvist, C., 2019. Shaping tomorrow's facilities management. Facilities 37, 366-380. https://doi.org/10.1108/F-10-2018-0126

Burke, M.C., Edell, J.A., 1986. Ad Reactions over Time: Capturing Changes in the Real World. J CONSUM RES 13, 114. https://doi.org/10.1086/209051

Carrico, A.R., Riemer, M., 2011. Motivating energy conservation in the workplace: An evaluation of the use of group-level feedback and peer education. Journal of Environmental Psychology 31, 1-13. https://doi.org/10.1016/j.jenvp.2010.11.004

Ceglia, D., de Oliveira Lima, S.H., Leocádio, Á.L., 2015. An Alternative Theoretical Discussion on Cross-Cultural Sustainable Consumption: A Theoretical Discussion on Sustainable Consumption. Sust. Dev. 23, 414-424. https://doi.org/10.1002/sd.1600

Chaplin, G., Wyton, P., 2014. Student engagement with sustainability: understanding the value-action gap. Int J of Sus in Higher Ed 15, 404-417. https://doi.org/10.1108/IJSHE-04-2012-0029

Clayton, S., 2003. Environmental identity: A conceptual and an operational definition. Identity and the natural environment: The psychological significance of nature 45-65.

Csutora, M., 2012. One More Awareness Gap? The Behaviour-Impact Gap Problem. J Consum Policy 35, 145-163. https://doi.org/10.1007/s10603-012-9187-8

Ding, G.K.C., 2008. Sustainable construction-The role of environmental assessment tools. Journal of Environmental Management 86, 451-464. https://doi.org/10.1016/j.jenvman.2006.12.025

Doherty, T.J., Clayton, S., 2011. The psychological impacts of global climate change. American Psychologist 66, 265.

Dunlap, R.E., McCright, A.M., 2010. Climate change denial: sources, actors and strategies, in: Routledge Handbook of Climate Change and Society. pp. 270-290.

Earle, T.C., 2004. Thinking Aloud about Trust: A Protocol Analysis of Trust in Risk Management. Risk Analysis 24, 169-183. https://doi.org/10.1111/j.02724332.2004.00420.x 
Ehrlich, P., Ornstein, R., 1989. New World, New Mind--Changing the way we think to save our future. London, UK: Paladin.

Fastighetsägarna, 2017. Grönt hyresavtal, en handledning till formulär 99.

Feygina, I., Jost, J.T., Goldsmith, R.E., 2010. System Justification, the Denial of Global Warming, and the Possibility of "System-Sanctioned Change." Pers Soc Psychol Bull 36, 326-338. https://doi.org/10.1177/0146167209351435

Gaspar, R., 2013. Understanding the Reasons for Behavioral Failure: A Process View of Psychosocial Barriers and Constraints to Pro-Ecological Behavior. Sustainability 5, 2960-2975. https://doi.org/10.3390/su5072960

Gaspar, R., Antunes, D., Faria, A., Meiszner, A., 2017. Sufficiency before efficiency: Consumers' profiling and barriers/facilitators of energy efficient behaviours. Journal of Cleaner Production 165, 134-142. https://doi.org/10.1016/j.jclepro.2017.07.075

Gifford, R., 2015. The road to climate hell. New Scientist 227, 28-33. https://doi.org/10.1016/S0262-4079(15)30744-2

Gifford, R., 2011. The dragons of inaction: psychological barriers that limit climate change mitigation and adaptation. American psychologist 66, 290.

Gifford, R., 2008. Psychology's essential role in alleviating the impacts of climate change. Canadian Psychology/Psychologie canadienne 49, 273-280. https://doi.org/10.1037/a0013234

Gifford, R., 1976. Environmental Numbness in the Classroom. The Journal of Experimental Education 44, 4-7. https://doi.org/10.1080/00220973.1976.11011527

Gifford, R., Nilsson, A., 2014. Personal and social factors that influence pro-environmental concern and behaviour: A review: PERSONAL AND SOCIAL FACTORS THAT INFLUENCE PRO-ENVIRONMENTAL BEHAVIOUR. Int J Psychol n/a-n/a. https://doi.org/10.1002/ijop.12034

Gifford, R., Scannell, L., Kormos, C., Smolova, L., Biel, A., Boncu, S., Corral, V., Güntherf, H., Hanyu, K., Hine, D., Kaiser, F.G., Korpela, K., Lima, L.M., Mertig, A.G., Mira, R.G., Moser, G., Passafaro, P., Pinheiro, J.Q., Saini, S., Sako, T., Sautkina, E., Savina, Y., Schmuck, P., Schultz, W., Sobeck, K., Sundblad, E.-L., Uzzell, D., 2009. Temporal pessimism and spatial optimism in environmental assessments: An 18-nation study. Journal of Environmental Psychology 29, 1-12. https://doi.org/10.1016/j.jenvp.2008.06.001

Gifford, R.D., Chen, A.K.S., 2017. Why aren't we taking action? Psychological barriers to climate-positive food choices. Climatic Change 140, 165-178. https://doi.org/10.1007/s10584-016-1830-y

Grifford, R., 2011. The dragons of inaction: psychological barriers that limit climate change mitigation and adaptation. American psychologist 66, 290.

Guardian, 2018. The Six Weeks That Brought Cambridge Analytica Down. [WWW Document]. Guardian. URL HTTPS://WWW.THEGUARDIAN.COM/UKNEWS/2018/MAY/03/CAMBRIDGE-ANALYTICA (accessed 4.10.18).

Gynther, L., Mikkonen, I., Smits, A., 2012. Evaluation of European energy behavioural change programmes. Energy Efficiency 5, 67-82. https://doi.org/10.1007/s12053-011-9115-9

Hammink, C., Moor, N., Mohammadi, M., 2019. A systematic literature review of persuasive architectural interventions for stimulating health behaviour. $F 37,743-761$. https://doi.org/10.1108/F-07-2017-0065 
Hatfield, J., Soames Job, R.F., 2001. OPTIMISM BIAS ABOUT ENVIRONMENTAL DEGRADATION: THE ROLE OF THE RANGE OF IMPACT OF PRECAUTIONS. Journal of Environmental Psychology 21, 17-30. https://doi.org/10.1006/jevp.2000.0190

Hay, R., Eagle, L., Saleem, M.A., Vandommele, L., Li, S., 2019. Student perceptions and trust of sustainability information. IJSHE 20, 726-746. https://doi.org/10.1108/IJSHE-122018-0233

Heath, Y., Gifford, R., 2006. Free-Market Ideology and Environmental Degradation: The Case of Belief in Global Climate Change. Environment and Behavior 38, 48-71. https://doi.org/10.1177/0013916505277998

Herring, H., 2011. Dealing with rebound effects. ECEEE Summer Study 6-11 Jun 2011. Hine, D.W., Gifford, R., 1996. Individual Restraint and Group Efficiency in Commons Dilemmas: The Effects of Two Types of Environmental Uncertainty1. J Appl Social Pyschol 26, 993-1009. https://doi.org/10.1111/j.1559-1816.1996.tb01121.x

Hoggan, J., Littlemore, R.D., 2009. Climate cover-up the crusade to deny global warming. Greystone Books : Distributed in the U.S. by Publishers Group West, Vancouver; Berkeley.

Horhota, M., Asman, J., Stratton, J.P., Halfacre, A.C., 2014. Identifying behavioral barriers to campus sustainability: A multi-method approach. Int J of Sus in Higher Ed 15, 343358. https://doi.org/10.1108/IJSHE-07-2012-0065

Hunt, A., Watkiss, P., 2011. Climate change impacts and adaptation in cities: a review of the literature. Climatic Change 104, 13-49. https://doi.org/10.1007/s10584-010-9975-6

Imperatives, S., 1987. Report of the World Commission on Environment and Development: Our common future. Accessed Feb 10.

International Energy Agency (IEA) Global CO2 emissions [WWW Document], n.d. URL https://www.iea.org/articles/global-co2-emissions-in-2019 (accessed 3.3.20).

Jevons, W.S., 1865. On the Variation of Prices and the Value of the Currency since 1782. Journal of the Statistical Society of London 28, 294-320. https://doi.org/10.2307/2338419

Kibert, C.J., 2016. Sustainable construction: green building design and delivery, Fourth edition. ed. Wiley, Hoboken, New Jersey.

Kollmuss, A., Agyeman, J., 2002. Mind the Gap: Why do people act environmentally and what are the barriers to pro-environmental behavior? Environmental Education Research 8, 239-260. https://doi.org/10.1080/13504620220145401

Lombardi, P., Trossero, E., 2013. Beyond energy efficiency in evaluating sustainable development in planning and the built environment. International Journal of Sustainable Building Technology and Urban Development 4, 274-282. https://doi.org/10.1080/2093761X.2013.817360

Macias, T., 2015. Environmental risk perception among race and ethnic groups in the United States. Ethnicities 16, 111-129. https://doi.org/10.1177/1468796815575382

MacKenzie, I.A., 2018. The recycling crisis in Australia: easy solutions to a hard problem. The Conversation Media Trust.

Martin, P.R., Cheung, F.M., Knowles, M.C., Kyrios, M., Littlefield, L., Overmier, J.B., Prieto, J.M., 2011. IAAP Handbook of Applied Psychology, Blackwell laap Handbooks of Applied Psychology. Wiley.

Miller, D.T., 1999. The norm of self-interest. American Psychologist 54, 1053-1060. https://doi.org/10.1037/0003-066X.54.12.1053 
Mortreux, C., Barnett, J., 2009. Climate change, migration and adaptation in Funafuti, Tuvalu. Global Environmental Change 19, 105-112. https://doi.org/10.1016/j.gloenvcha.2008.09.006

National Waste Report 2018. Prepared for Dept of the Environment and Energy., 2018. Blue Environment.

Newig, J., 2004. Public Attention, Political Action: the Example of Environmental Regulation. Rationality and Society 16, 149-190. https://doi.org/10.1177/1043463104043713

Newton, P., Meyer, D., 2013. Exploring the Attitudes-Action Gap in Household Resource Consumption: Does "Environmental Lifestyle" Segmentation Align with Consumer Behaviour? Sustainability 5, 1211-1233. https://doi.org/10.3390/su5031211

Nicholson-Cole, S.A., 2005. Representing climate change futures: a critique on the use of images for visual communication. Computers, Environment and Urban Systems 29, 255-273. https://doi.org/10.1016/j.compenvurbsys.2004.05.002

Norgaard, K.M., 2006. "We Don't Really Want to Know": Environmental Justice and Socially Organized Denial of Global Warming in Norway. Organization \& Environment 19, 347-370. https://doi.org/10.1177/1086026606292571

Olson, M., 1989. Collective action, in: The Invisible Hand. Springer, pp. 61-69.

Osmani, M., Glass, J., Price, A.D.F., 2008. Architects' perspectives on construction waste reduction by design. Waste Management 28, 1147-1158. https://doi.org/10.1016/j.wasman.2007.05.011

Pahl, S., Harris, P.R., Todd, H.A., Rutter, D.R., 2005. Comparative optimism for environmental risks. Journal of Environmental Psychology 25, 1-11. https://doi.org/10.1016/j.jenvp.2004.12.004

Pahl, S., Sheppard, S., Boomsma, C., Groves, C., 2014. Perceptions of time in relation to climate change: Perceptions of time in relation to climate change. WIREs Clim Change 5, 375-388. https://doi.org/10.1002/wcc.272

Patton, M.Q., 2002. Qualitative designs and data collection. Qualitative research \& evaluation methods 207, 257.

Pelletier, L.G., Lavergne, K.J., Sharp, E.C., 2008. Environmental psychology and sustainability: Comments on topics important for our future. Canadian Psychology/Psychologie canadienne 49, 304-308. https://doi.org/10.1037/a0013658

Pongiglione, F., 2014. Motivation for Adopting Pro-environmental Behaviors: The Role of Social Context. Ethics, Policy \& Environment 17, 308-323. https://doi.org/10.1080/21550085.2014.955318

Preston, B.L., Jones, R., 2006. Climate change impacts on Australia and the benefits of early action to reduce global greenhouse gas emissions. CSIRO Canberra.

Rameezdeen, R., Zuo, J., Ochoa Paniagua, J., Wood, A., Do, P., 2019. Ensuring environmental performance in green leases: the role of facilities managers. Facilities 37, 527-549. https://doi.org/10.1108/F-01-2018-0017

Rickard, L.N., Yang, Z.J., Seo, M., Harrison, T.M., 2014. The "I" in climate: The role of individual responsibility in systematic processing of climate change information. Global Environmental Change 26, 39-52. https://doi.org/10.1016/j.gloenvcha.2014.03.010

Rode, P., Burdett, R., 2011. Cities: investing in energy and resource efficiency. United Nations Environment Programme. 
Roy, A., Goll, I., 2014. Predictors of various facets of sustainability of nations: The role of cultural and economic factors. International Business Review 23, 849-861. https://doi.org/10.1016/j.ibusrev.2014.01.003

Schiffman, L., Kanuk, L., Das, M., 2006. Consumer behaviour. Canada.

Schultz, P.W., Nolan, J.M., Cialdini, R.B., Goldstein, N.J., Griskevicius, V., 2007. The Constructive, Destructive, and Reconstructive Power of Social Norms. Psychol Sci 18, 429-434. https://doi.org/10.1111/j.1467-9280.2007.01917.x

Sieminski, A., 2013. International energy outlook 2013. US Energy Information Administration (EIA) Report Number: DOE/EIA-0484.

Steg, L., Vlek, C., 2009. Encouraging pro-environmental behaviour: An integrative review and research agenda. Journal of Environmental Psychology 29, 309-317. https://doi.org/10.1016/j.jenvp.2008.10.004

Stern, P.C., 2000. New Environmental Theories: Toward a Coherent Theory of Environmentally Significant Behavior. J Social Isssues 56, 407-424. https://doi.org/10.1111/0022-4537.00175

Stevenson, F., Leaman, A., 2010. Evaluating housing performance in relation to human behaviour: new challenges. Building Research \& Information 38, 437-441. https://doi.org/10.1080/09613218.2010.497282

Sundblad, E.-L., Biel, A., Gärling, T., 2007. Cognitive and affective risk judgements related to climate change. Journal of Environmental Psychology 27, 97-106. https://doi.org/10.1016/j.jenvp.2007.01.003

Swim, J., Clayton, S., Doherty, T., Gifford, R., Howard, G., Reser, J., Stern, P., Weber, E., 2009. Psychology and global climate change: Addressing a multi-faceted phenomenon and set of challenges. A report by the American Psychological Association's task force on the interface between psychology and global climate change. American Psychological Association, Washington.

Terwel, B.W., Harinck, F., Ellemers, N., Daamen, D.D.L., 2009. Competence-Based and Integrity-Based Trust as Predictors of Acceptance of Carbon Dioxide Capture and Storage (CCS). Risk Analysis 29, 1129-1140. https://doi.org/10.1111/j.15396924.2009.01256.x

Thissen, D., Steinberg, L., Kuang, D., 2002. Quick and Easy Implementation of the BenjaminiHochberg Procedure for Controlling the False Positive Rate in Multiple Comparisons. Journal of Educational and Behavioral Statistics 27, 77-83. https://doi.org/10.3102/10769986027001077

Thøgersen, J., 2008. Social norms and cooperation in real-life social dilemmas. Journal of Economic Psychology 29, 458-472. https://doi.org/10.1016/j.joep.2007.12.004

Uzzell, D.L., 2000. THE PSYCHO-SPATIAL DIMENSION OF GLOBAL ENVIRONMENTAL PROBLEMS. Journal of Environmental Psychology 20, 307-318. https://doi.org/10.1006/jevp.2000.0175

van der Werff, E., Steg, L., Keizer, K., 2013. It is a moral issue: The relationship between environmental self-identity, obligation-based intrinsic motivation and proenvironmental behaviour. Global Environmental Change 23, 1258-1265. https://doi.org/10.1016/j.gloenvcha.2013.07.018

Vaughan, E., Nordenstam, B., 1991. The Perception of Environmental Risks among Ethnically Diverse Groups. Journal of Cross-Cultural Psychology 22, 29-60. https://doi.org/10.1177/0022022191221005 
Weber, E.U., 2006. Experience-Based and Description-Based Perceptions of Long-Term Risk: Why Global Warming does not Scare us (Yet). Climatic Change 77, 103-120. https://doi.org/10.1007/s10584-006-9060-3

Weber, E.U., Stern, P.C., 2011. Public understanding of climate change in the United States. American Psychologist 66, 315.

Weinstein, N.D., Klotz, M.L., Sandman, P.M., 1988. Optimistic biases in public perceptions of the risk from radon. Am J Public Health 78, 796-800. https://doi.org/10.2105/AJPH.78.7.796

Wilkinson, S.J., 2018. The 1200 Buildings Experience in Melbourne - reflections on a voluntary approach to delivering in Real Estate., in: Wilkinson, S.J., Dixon, T.J., Miller, N., Sayce, S. (Eds.), Routledge Handbook of Sustainable Real Estate. Taylor \& Francis.

Xiao, F., Wang, S., 2009. Progress and methodologies of lifecycle commissioning of HVAC systems to enhance building sustainability. Renewable and Sustainable Energy Reviews 13, 1144-1149. https://doi.org/10.1016/j.rser.2008.03.006 


\begin{tabular}{|c|c|c|c|c|c|c|c|}
\hline $\begin{array}{l}\text { General psychological } \\
\text { barrier }\end{array}$ & $\begin{array}{l}\text { specific } \\
\text { manifestations/variables }\end{array}$ & survey question & $\begin{array}{c}\text { Strongly } \\
\text { agree }\end{array}$ & Agree & $\begin{array}{c}\begin{array}{c}\text { Neither agree } \\
\text { nor disagree }\end{array} \\
\end{array}$ & Disagree & $\begin{array}{l}\text { Strongly } \\
\text { disagree }\end{array}$ \\
\hline \multirow[t]{7}{*}{ 1Limited cognition } & 1.1 Ancient brain & $\begin{array}{l}\text { Climate change is distant and not related to my everyday life } \\
\text { or family and close friends }\end{array}$ & $1 \%$ & $3 \%$ & $3 \%$ & $54 \%$ & $39 \%$ \\
\hline & 1.2 Ignorance & to know more to take action to mitigate climate change & $8 \%$ & $32 \%$ & $18 \%$ & $30 \%$ & $11 \%$ \\
\hline & 1.3 Environmental numbness & $\begin{array}{l}\text { Climate change is never out of the media, on the television, in the } \\
\text { newspapers and on the radio. I get sick of hearing about it. }\end{array}$ & $3 \%$ & $6 \%$ & $17 \%$ & $39 \%$ & $35 \%$ \\
\hline & 1.4 Uncertainty & $\begin{array}{l}\text { The Inter-governmental Panel on Climate Change says } 2 \text { degrees of } \\
\text { warming is 'likely' -I'm not sure what that means. }\end{array}$ & $3 \%$ & $14 \%$ & $14 \%$ & $35 \%$ & $34 \%$ \\
\hline & 1.5 Judgemental discounting & $\begin{array}{l}\text { I believe that the effects of climate change are worse in my home } \\
\text { country compared to other countries. }\end{array}$ & $15 \%$ & $14 \%$ & $30 \%$ & $32 \%$ & $8 \%$ \\
\hline & 1.6 Optimism bias & I believe my actions will stop climate change. & $3 \%$ & $27 \%$ & $35 \%$ & $27 \%$ & $8 \%$ \\
\hline & $\begin{array}{l}\text { 1.7 Perceived behavioural } \\
\text { control }\end{array}$ & $\begin{array}{l}\text { Individuals can effect climate change. Action doesn't have to be at } \\
\text { government and national levels. }\end{array}$ & $18 \%$ & $37 \%$ & $15 \%$ & $24 \%$ & $6 \%$ \\
\hline \multirow[t]{4}{*}{ 2. Ideologies } & 2.1 Worldviews & I believe in capitalism. & $6 \%$ & $18 \%$ & $46 \%$ & $15 \%$ & $14 \%$ \\
\hline & 2.2 Suprahuman & What ever actions humans takes, mother nature will do her thing. & $8 \%$ & $24 \%$ & $18 \%$ & $31 \%$ & $18 \%$ \\
\hline & 2.3 Technosalvation & Humans will find a technological solution to climate change. & $6 \%$ & $25 \%$ & $25 \%$ & $35 \%$ & $8 \%$ \\
\hline & 2.4 System justification & $\begin{array}{l}\text { Things are } O K \text { as they stand, that's why I don't need to take any } \\
\text { action on climate change. }\end{array}$ & $0 \%$ & $4 \%$ & $3 \%$ & $32 \%$ & $61 \%$ \\
\hline \multirow[t]{2}{*}{$\begin{array}{l}\text { 3.Comparision with } \\
\text { others }\end{array}$} & 3.2 Social norms and networks & $\begin{array}{l}\text { If I was told that my energy usage was higher than my friends that } \\
\text { would prompt me to reduce it to a comparable level. }\end{array}$ & $31 \%$ & $41 \%$ & $24 \%$ & $4 \%$ & $0 \%$ \\
\hline & 3.3 Perceived inequity & Why should I take action when others don't. & $0 \%$ & $7 \%$ & $7 \%$ & $34 \%$ & $52 \%$ \\
\hline
\end{tabular}




\begin{tabular}{|c|c|c|c|c|c|c|c|}
\hline $\begin{array}{l}\text { General psychological } \\
\text { barrier }\end{array}$ & $\begin{array}{l}\text { specific } \\
\text { manifestations/variables }\end{array}$ & survey question & $\begin{array}{c}\text { Strongly } \\
\text { agree }\end{array}$ & Agree & $\begin{array}{c}\text { Neither agree } \\
\text { nor disagree }\end{array}$ & Disagree & $\begin{array}{l}\text { Strongly } \\
\text { disagree }\end{array}$ \\
\hline \multirow[t]{3}{*}{ 4.Sunk costs } & 4.1 Financial investment & $\begin{array}{l}\text { If I own a perfectly good car, it would be irrational to take public } \\
\text { transport. }\end{array}$ & $1 \%$ & $1 \%$ & $18 \%$ & $38 \%$ & $41 \%$ \\
\hline & 4.2 Behavioural momentum & $\begin{array}{l}\text { If taking action on climate change depends on me changing my } \\
\text { daily routine quite a bit, it's not going to happen. }\end{array}$ & $3 \%$ & $8 \%$ & $15 \%$ & $42 \%$ & $31 \%$ \\
\hline & $\begin{array}{l}4.3 \text { Conflicting values, goals, and } \\
\text { aspirations }\end{array}$ & $\begin{array}{l}\text { I believe climate change is real, but I am unwilling to pay higher } \\
\text { taxes to tackle it. }\end{array}$ & $3 \%$ & $18 \%$ & $15 \%$ & $45 \%$ & $18 \%$ \\
\hline \multirow[t]{4}{*}{ 5. Discredence } & 5.1 Mistrust & $\begin{array}{l}\text { 1 don't trust government departments and their reports on } \\
\text { environmental matters. }\end{array}$ & $4 \%$ & $25 \%$ & $31 \%$ & $31 \%$ & $8 \%$ \\
\hline & $\begin{array}{l}5.2 \text { Perceived program } \\
\text { inadequacy }\end{array}$ & $\begin{array}{l}\text { Policy makers programmes, for example incentives for solar panels, } \\
\text { are good idea but there is too much paperwork. }\end{array}$ & $11 \%$ & $30 \%$ & $44 \%$ & $11 \%$ & $4 \%$ \\
\hline & 5.3 Denial & Human activity has little, or nothing, to do with climate change. & $0 \%$ & $0 \%$ & $10 \%$ & $18 \%$ & $72 \%$ \\
\hline & 5.4 Reactance & $\begin{array}{l}\text { The government is imposing too many rules and regulations about } \\
\text { climate change. }\end{array}$ & $3 \%$ & $4 \%$ & $24 \%$ & $41 \%$ & $27 \%$ \\
\hline \multirow[t]{3}{*}{ 7.Limited behaviour } & 7.1 Rebound effect & $\begin{array}{l}\text { After all the savings (energy, water, CO2) I have made, I believe I } \\
\text { deserve a reward. }\end{array}$ & $1 \%$ & $10 \%$ & $19 \%$ & $44 \%$ & $26 \%$ \\
\hline & 7.2 Tokenism & 列 & $4 \%$ & $4 \%$ & $32 \%$ & $38 \%$ & $21 \%$ \\
\hline & & & yes & & $\begin{array}{l}\text { don't know. } \\
\text { don't compare }\end{array}$ & & no \\
\hline $\begin{array}{l}3^{*} \text {.Comparision with } \\
\text { others }\end{array}$ & 3.1 Social comparision* & I recycle as much as my friends do. & $33 \%$ & $0 \%$ & $54 \%$ & $0 \%$ & $13 \%$ \\
\hline
\end{tabular}

Table 1. Questions describing 23 different manifestations of general psychological barriers. All questions except one (question 3.1) gave respondents possibility of 5 answers: strongly agree /agree/neither agree or disagree / disagree/ strongly disagree. Question 3.1 offered 3 possible answers: yes / no / I do not know, I do not compare. 
1
2
3
4
5
6
7
8
9 